\title{
Effect of Acid Activation on Adsorption of Iron and Manganese Using Libyan Bentonite Clay
}

\author{
HAMDI A. M. BENNOUR \\ Department of Chemistry, Faculty of Science, Benghazi University, Benghazi, Libya \\ hamdibennour@yahoo.co.uk
}

Received 9 December 2016 / Accepted 21 December 2016

\begin{abstract}
The pollution by heavy metals currently is becoming a big challenge and a concern for the water quality and also for the environment in general. Some metal ions are toxic even if their concentration is very low and their toxicity increases with accumulation in water and soils. Several industrial wastewater streams may contain heavy metals such as, $\mathrm{Pb}, \mathrm{Cr}, \mathrm{Cd}, \mathrm{Ni}, \mathrm{Fe}, \mathrm{Mn}$ as well as $\mathrm{Zn}, \mathrm{As}, \mathrm{Hg}, \mathrm{Cu}$ and $\mathrm{Ag}$. The clays have been extensively utilized for the removal of heavy metals from aqueous solutions. The aim of this research work was to prepare acid activated bentonite clay by using $\mathrm{H}_{2} \mathrm{SO}_{4}$ and $\mathrm{C}_{2} \mathrm{H}_{4} \mathrm{O}_{2}$ as acid chemical reagents. The adsorption capacity of natural and acid activated bentonite clay with iron and manganese was also investigated. The removal of two heavy metals was studied at $25{ }^{\circ} \mathrm{C}$. Both modified forms showed higher adsorption efficiency than the natural clay. Moreover, the empirical values were evaluated according to the Freundlich isotherms that are generally used to describe the adsorption processes. The heavy metal-clay adsorption phenomena can be illustrated on the basis of the interaction between surface functional group of silicates (clay) and the metal ions. It is deduced that clay can be used as a low cost adsorbent and locally available for the removal of heavy metals, especially in the developing countries.
\end{abstract}

Keywords: Acid activation, Adsorption, Iron, Manganese, Bentonite

\section{Introduction}

The increasing problems of dispersion of heavy metals in the environment as the result of mining and industrial activities have caused extensive heavy metal contamination by introducing heavy metals directly into the surrounding environment ${ }^{1-6}$. Heavy metals were extensively known of difficulty to eliminate. The biological treatment could not be applied to treat effluent water with metal contaminants due to their inhibitory ability on bacteria in the system ${ }^{7}$. The physical and chemical treatment has been used in metal effluent removal. The adsorption method with different types of adsorbent has been used to treat these metals from waste water ${ }^{8-11}$. Iron and manganese are the most common elements in the groundwater supplies (Sequestering methods of iron and manganese treatment). Iron is the more frequent of these two contaminants, but they often occurs together ${ }^{12}$. Iron accounts for about $5 \%$ of the earth's crust, making it the second most abundant metal ${ }^{13,14}$. Iron and manganese are more 
common in deeper wells where the water has been in contact with the rocks for a long time. The high levels of iron and manganese can discolour the water, stain the plumbing fixtures and give water an unpleasant metallic taste ${ }^{15}$. The iron and manganese elements in water occur in various forms ${ }^{16-18}$. In the water tap, the iron and manganese are present in dissolved forms. When the water tap comes out rust-colored, this indicates that the iron and manganese are in precipitate forms. When the water tap has a clear yellow tint, this means that the iron and manganese are combined with organic materials. The environmental protection Agency (EPA) determines the maximum contamination levels of iron and manganese by $0.3 \mathrm{mg} / \mathrm{L}$ and $0.4 \mathrm{mg} / \mathrm{L}$ respectively, due to their health effects. Various physicochemical methods have been used to remove and adjust the heavy metals in drinking water ${ }^{19-23}$, ion exchange ${ }^{24}$. The adsorption process is one of the most popular technologies due to its effective and economic properties ${ }^{25,26}$. Their sorption capabilities come from their high surface areas and their ion exchange capacities. The negative charges on the structure of clay minerals give the capability to attract metal ions ${ }^{27}$. The use of clay materials as adsorbents is becoming a very promising alternative as compared to aluminium sulfate for water treatment, since they are inexpensive, abundant and efficient. In fact clays are 20 times cheaper than activated carbon $^{28}$. Kaolin is the most clay type abundant phyllosilicate mineral in highly weathered soils $^{29,30}$. Bentonite is widely available in the form of aluminium hydrous silicate $\left(\mathrm{Al}_{2} \mathrm{O}_{3} \cdot 2 \mathrm{SiO}_{2} \cdot 2 \mathrm{H}_{2} \mathrm{O}\right)^{31,32}$. The acid activation of clays is one of the most important processes that have been applied to achieve structural modifications in the clays. During the acid activation, initially the inter-layer's cations are replaced by $\mathrm{H}^{+}$ions followed by partial destruction of aluminium octahedral sheets after that a dissolution of structural cations occur. The desired changes in the physicochemical properties of clay occurred as a result of acid activation depend considerably on the condition of acid activation such as acid concentration and the duration of the activation process ${ }^{30,32}$. In this study, clay was used for removing iron and manganese from aqueous solutions in some wells in Libya and increasing of its efficiency to remove heavy metals by applying adsorption on raw washed clay and its acid activated forms by using sulphuric and acetic acids. In order to determine the reaction of Iron and manganese with clay, experimental results were applied to Freundlich adsorption isotherms.

\section{Experimental}

Iron and manganese certified reference materials (CRM) are provided by Merck, Co. (Germany). Nitric acid 65\% suprapur ${ }^{\circledR}$ degree is provided by Merck, Co.(Germany).Acetic and sulphuric acids were supplied by Fluka, Sigma-Aldrich, Co.(Germany). Double distilled water was used to prepare all solutions.

\section{Natural clay pre-treatment (Collection and Preparation)}

The clay samples used in this study were collected from Umm-Ar-Razam area, located in the north east region of Libya; the upper layers of the earth crust in this area are mostly limestone, while the lower layers consist mainly of bentonite. The bentonite samples collected at depth 3-9 meters and from six different drilling sites, the samples were allowed to dry in air. The ore lumps obtained were fragmented to smaller pieces by a steel hammer and then crushed to below $10 \mathrm{~mm}$ particles using a Jaw-Crusher. A representation sample was obtained from the six crushed ore samples by the method of quartering ${ }^{34}$. Then these samples (about $5 \mathrm{~kg}$ ) were further dried at $105-110{ }^{\circ} \mathrm{C}$, the pre-treatment of bentonite was carried out by milling it to the sub micro size to obtain grain size $\sim 200$ mesh $(74 \mu)$, this particle size was needed for complete chemical and $\mathrm{x}$-ray analysis as well as for adsorption experiments. 


\section{Chemical analysis of the ore}

1 gram of bentonite clay sample was mixed with 1 gram of $\mathrm{Na}_{2} \mathrm{CO}_{3}$ and the mixture was fused at $1000{ }^{\circ} \mathrm{C}$ using platinum crucible, the fusion product was extracted with $\mathrm{HCl}$ solution $(100$ $\mathrm{mL}, 1: 1)$, then filtered and washed. The filtrate and washing were completed to $500 \mathrm{~mL}$ measuring flask. Such solution was used for determination of $\mathrm{Al}_{2} \mathrm{O}_{3}, \mathrm{CaO}, \mathrm{MgO}, \mathrm{Fe}_{2} \mathrm{O}_{3}, \mathrm{Mn}$, $\mathrm{Cu}$ and $\mathrm{Zn}$ using standard methods ${ }^{35}$. Moisture content was determined using moisture balance. The chemical and physical properties of bentonite clay are given in Table 1. Silica and alumina are their major constituents along with traces of sodium, magnesium, calcium, potassium and titanium oxides as impurities. The $\mathrm{Ca}^{+2}$ are present on the surface of bentonite clay are considered as important adsorption sites for cation exchange are given in the Table 2.

Table 1. Chemical and physical properties of Umm-Ar-Razam bentonite sample, wt (\%)

\begin{tabular}{cc}
\hline Chemical compound (on dry basis) & $\%$ \\
\hline $\mathrm{Al}_{2} \mathrm{O}_{3}$ & 19.00 \\
$\mathrm{SiO}_{2}$ & 34.70 \\
$\mathrm{Fe}_{2} \mathrm{O}_{3}$ & 7.35 \\
$\mathrm{CaO}$ & 7.98 \\
$\mathrm{MgO}^{2-}$ & 2.35 \\
$\mathrm{SO}_{4}{ }^{2-}$ & 0.765 \\
$\mathrm{P}$ & $1.5 \mathrm{ppm}$ \\
$\mathrm{Moisture}$ & 10.23 \\
$\mathrm{L.O.I}$ & 13.59 \\
Organic Matter & 0.279 \\
Organic Carbon & 0.162 \\
$\mathrm{~K}_{2} \mathrm{O}$ & 1.34 \\
$\mathrm{TiO}$ & 0.02 \\
$\mathrm{Na}_{2} \mathrm{O}$ & 1.44 \\
$\mathrm{Cu}$ & $0.45 \mathrm{ppm}$ \\
$\mathrm{Zn}$ & $0.66 \mathrm{ppm}$ \\
$\mathrm{N}$ & 0.02 \\
Dry particle size & Min. 75\% pass through 200 mesh \\
\hline
\end{tabular}

Table 2. Exchangeable cations

$\begin{array}{cr}\mathrm{Mg}^{++} & 15.40 \mathrm{meq} / 100 \mathrm{~g} \\ \mathrm{Ca}^{++} & 12.27 \mathrm{meq} / 100 \mathrm{~g} \\ \mathrm{Na}^{+} & 10.20 \mathrm{meq} / 100 \mathrm{~g} \\ \mathrm{~K}^{+} & 8.80 \mathrm{meq} / 100 \mathrm{~g}\end{array}$

\section{Characterization}

Electrical Conductivity: (E.C) of the paste 17.8 milli moh's

The x-ray diffraction (XRD) patterns of the adsorbents were obtained using a Philips x-ray diffraction instrument with filtered $\mathrm{Cu} \mathrm{K \alpha}$ radiation $(\mathrm{n}=1.6418 \AA$ ) operated at $40 \mathrm{kV}$ and $40 \mathrm{~mA}$, The XRD pattern was recorded from 1.5 to $50^{\circ} 2 \theta$ with a scanning speed of $0.02^{\circ} 2 \theta$ per second (Figure 1). A Philip X 1.30 scanning electron microscopes/EDAX was used to obtain microgram scans of mineral clay samples. X-ray diffraction analysis of powdered bentonite sample showed the presence of the following minerals:

Montmorillonite $\left[\mathrm{Na}_{0.3}(\mathrm{Al}, \mathrm{Mg})_{2} \mathrm{Si}_{4} \mathrm{O}_{10}(\mathrm{OH})_{2} \cdot \mathrm{XH}_{2} \mathrm{O}\right]$

Kaolinite $\left[\mathrm{Al}_{2} \mathrm{Si}_{2} \mathrm{O}_{5}(\mathrm{OH})_{4}\right]$

Quartz $\left(\mathrm{SiO}_{2}\right)$

Gypsum $\left(\mathrm{CaSO}_{4} \cdot 2 \mathrm{H}_{2} \mathrm{O}\right)$ 


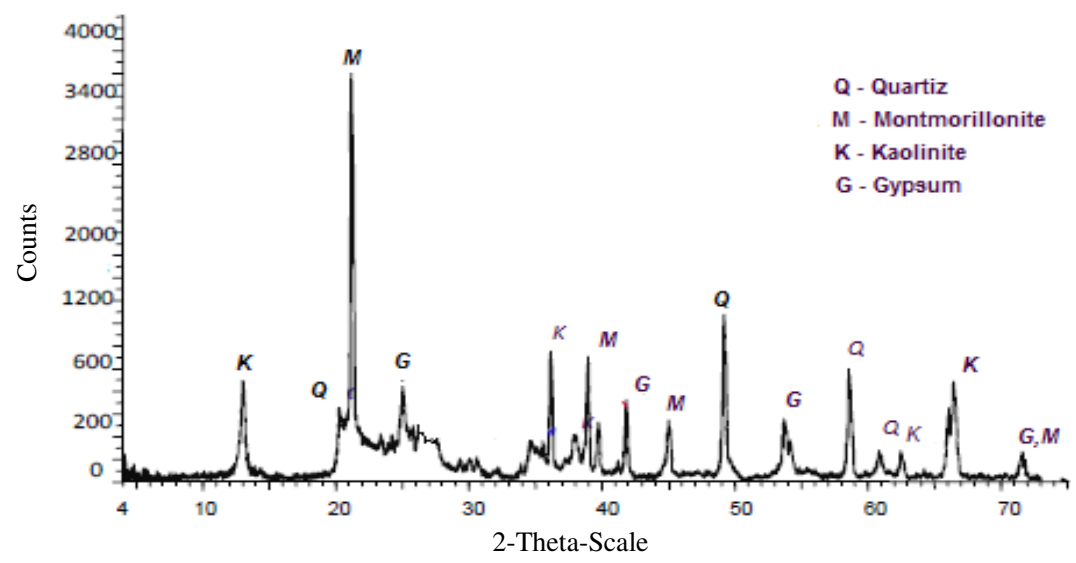

Figure 1. The XRD of the natural bentonite

\section{Modified clays}

There have been various attempts to improve the quality and characteristics of the clays by modifying them with different techniques. One of the common techniques in this regard is acid activation.

\section{Acid activation}

Activation of natural bentonite was carried out by taking $10 \mathrm{~g}$ of the clay in flask $(250 \mathrm{~mL}$ capacity) and $100 \mathrm{~mL}$ of $1 \mathrm{M} \mathrm{H}_{2} \mathrm{SO}_{4}$ solution was added. Then it was heated on a magnetically stirred hot plate at a temperature of $90{ }^{\circ} \mathrm{C}$ for 2 hours. The resulting slurry was filtered through a Buchner funnel to separate the clay from the acid solution. The residual clay was washed several times with distilled water till the $\mathrm{pH}$ reaches to 6-8. The clay residue was dried in an oven at $80^{\circ} \mathrm{C}$ for 3 hours. The dried acid activated clay was milled to sub micro particle size. The activation process was repeated with acetic acid.

\section{Stock solution preparation}

$1 \mathrm{~g}$ of each metals (iron and manganese) was dissolved in $2 \%$ nitric acid then made up to 1 litre using double distilled water in a standard flask and used as standard solution $(1000 \mathrm{mg} / \mathrm{L})$ of the metal ion. From this solution 200, 400, 600 and 800 ppm dilutions were prepared. Determination of $\mathrm{Fe}^{2+}$ and $\mathrm{Mg}^{2+}$ concentrations were done by atomic absorption spectrometer (AAS). Measurements showed that best sensitivity and accuracy of the spectrophotometer was in the range up to $5 \mathrm{ppm}$ and hence all solutions were diluted to be within that range.

\section{Batch adsorption studies}

The adsorption studies were carried out by using natural clay and its acidified activated forms (acetic acid and sulphuric acid) for the removal of iron and manganese. Batch adsorption experiments were carried out by shaking varied amounts of adsorbent materials with known concentrations ( $\mathrm{ppm}$ ) of stock solutions from iron and manganese (adsorbate materials) at room temperature or $25{ }^{\circ} \mathrm{C}$ in Jar test. At the end of predetermined time interval, the adsorbent was removed and filtered. The residual metal ions present in the liquor (filtrate) were analyzed by atomic absorption spectrometer (AAS). The amount of metal ions adsorbed on the adsorbent materials was calculated by subtracting the final concentration 
in solution from the initial one. Then the percent of adsorption was determined, for each element by each adsorbent material. The results are the mean of four measurements.

\section{Results and Discussion}

\section{Effect of contact time of iron and manganese on bentonite clay}

The time dependence of the adsorption of iron and manganese on adsorbent materials is given in Figures $2 \& 3$. The results show that the percentage adsorption increases with the increase in adsorption time. The metal ion removal was fast in the first 90 minutes, it may be due to the presence of additional sites on the clay for free cations ${ }^{36}$. In addition, presence of adsorption driving force at the beginning lead to higher adsorption rate which occur at first period. However, after 90 minutes, slower due to slower diffusion of iron and manganese ions into pores of clay $^{37}$, the optimum adsorption time for the removal of both iron and manganese from its solutions is 120 minutes.

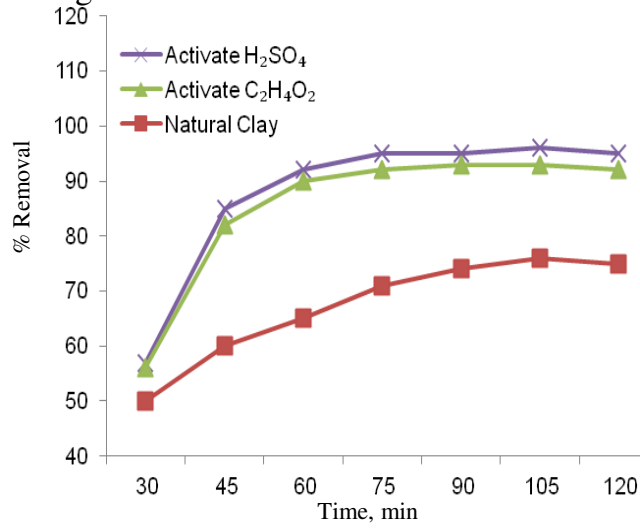

Figure 2. Effect of contact time on the removal of $\mathrm{Fe}$ using bentonite clay at $\mathrm{pH} 3.5$ and the concentration of metal ions $200 \mathrm{ppm}$ at room temperature

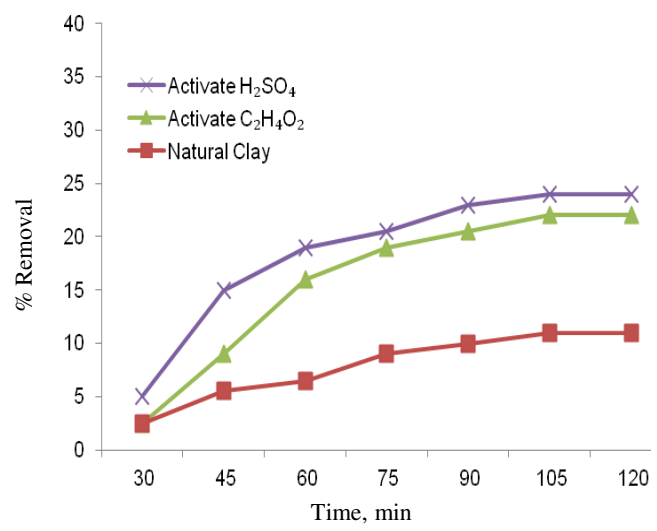

Figure 3. Effect of contact time on the removal of Mn using bentonite clay at $\mathrm{pH}$ 3.5 and the concentration of metal ions 200 ppm at room temperature

\section{Effect of $\mathrm{pH}$ on the sorption of iron and manganese on bentonite clay}

The process of cation exchange between solid surface and the solution containing the heavy metal cations is highly dependent on the $\mathrm{pH}$ value of the medium. The effect of varying the $\mathrm{pH}$ on the adsorption of iron and manganese was investigated and represented in Figures 4 \& 5 . These figures show that the adsorption of heavy metal ions gradually increases with increasing the $\mathrm{pH}$ until it reaches the maximum value at $\mathrm{pH}$ 7.5. The sorption of iron slightly increases at lower $\mathrm{pH}$ values until it reaches the range of 6.5 to 8.5 , at which the adsorption reaches high level. The sorption of manganese is very low below $\mathrm{pH} 4.5$ and increases rapidly at $\mathrm{pH} 6.5$ and coming to maximum at $\mathrm{pH} 8.5$. At higher $\mathrm{pH}$ the metal cations begin to hydrolyze and precipitate and hence become not available for adsorption. It may attributed to the sorption process depends on the concentration of the hydrogen ion in solution. Hydrogen ion strongly competes for the free sites in the structure of the clay leading to decrease in the percentage of adsorption of ions ${ }^{38}$. Increasing the $\mathrm{pH}$ of solution results in decrease in $\mathrm{H}^{+}$ion leading to low competition for the vacant exchange sites of the clay, and hence more removal of metal ions takes place. At $\mathrm{pH}>8$ (high alkaline media), the precipitation of the metal ion hydroxides may take place, thus, cations present in solution are exchanged with those on kaolin's structure ${ }^{39}$. The results of adsorption experiments are given in Tables $3 \& 4$. 


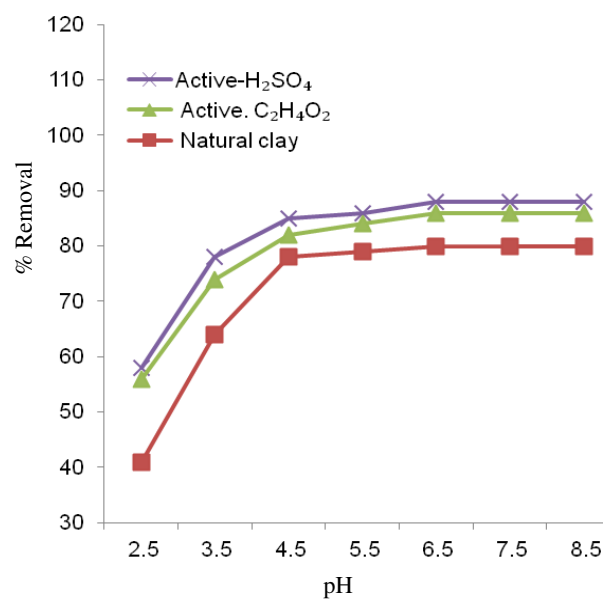

Figure 4. Effect of $\mathrm{pH}$ on the removal of $\mathrm{Fe}^{+2}$ using bentonite clay at clay's dose of $200 \mathrm{ppm}$ at room temperature

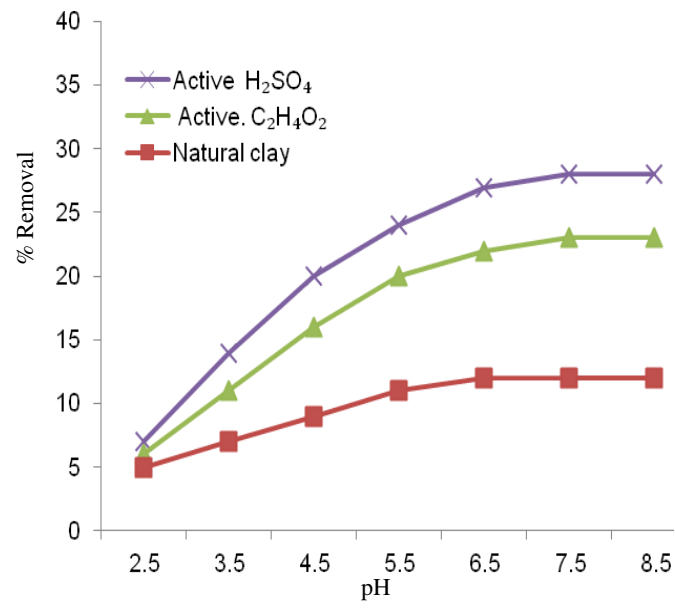

Figure 5. Effect of $\mathrm{pH}$ on the removal of $\mathrm{Mn}^{+2}$ using bentonite clay at clay's dose of $200 \mathrm{ppm}$ at room temperature

Table 3. Adsorption of $\mathrm{Fe}^{2+}$ ions on natural and treated bentonite at different $\mathrm{pH}$ values

\begin{tabular}{ccccc}
$\begin{array}{c}\text { Original conc. } \\
\text { of } \mathrm{Fe}^{+2}, \mathrm{ppm}\end{array}$ & $\mathrm{pH}$ & $\begin{array}{c}\mathrm{Fe}^{+2} \text { adsorbed on } \\
\text { natural clay, ppm }\end{array}$ & $\begin{array}{c}\mathrm{Fe}^{+2} \text { adsorbed on } \\
\text { treated clay with } \\
1 \mathrm{M} \mathrm{C}_{2} \mathrm{H}_{4} \mathrm{O}_{2}, \mathrm{ppm}\end{array}$ & $\begin{array}{c}\mathrm{Fe}^{+2} \text { adsorbed on } \\
\text { treated clay with } \\
1 \mathrm{M} \mathrm{H}_{2} \mathrm{SO}_{4}, \mathrm{ppm}\end{array}$ \\
\hline & & Natural clay & Active. $\mathrm{C}_{2} \mathrm{H}_{4} \mathrm{O}_{2}$ & Active- $\mathrm{H}_{2} \mathrm{SO}_{4}$ \\
\hline 200 & 2.5 & 42 & 56 & 58 \\
200 & 3.5 & 64 & 74 & 78 \\
200 & 4.5 & 78 & 82 & 85 \\
200 & 5.5 & 80 & 84 & 86 \\
200 & 6.5 & 82 & 86 & 88 \\
200 & 7.5 & 82 & 86 & 88 \\
200 & 8.5 & 82 & 86 & \\
\hline
\end{tabular}

Each reading is the average of four measurements

Table 4. Adsorption of $\mathrm{Mn}^{2+}$ ions on natural and treated bentonite at different $\mathrm{pH}$ values

\begin{tabular}{ccccc}
\hline $\begin{array}{c}\text { Original conc. } \\
\text { of } \mathrm{Mn}^{+2}, \mathrm{ppm}\end{array}$ & $\mathrm{pH}$ & $\begin{array}{c}\mathrm{Mn}+2 \text { adsorbed on } \\
\text { natural clay, ppm }\end{array}$ & $\begin{array}{c}\mathrm{Mn}^{+2} \text { adsorbed on } \\
\text { treated clay with } \\
1 \mathrm{M} \mathrm{C}_{2} \mathrm{H}_{4} \mathrm{O}_{2}, \mathrm{ppm}\end{array}$ & $\begin{array}{c}\mathrm{Mn}^{+2} \text { adsorbed on } \\
\text { treated clay with } \\
1 \mathrm{M} \mathrm{H}_{2} \mathrm{SO}_{4}, \mathrm{ppm}\end{array}$ \\
\hline & & Natural clay & Active $\mathrm{C}_{2} \mathrm{H}_{4} \mathrm{O}_{2}$ & Active $\mathrm{H}_{2} \mathrm{SO}_{4}$ \\
\hline 200 & 2.5 & 5 & 6 & 7 \\
200 & 3.5 & 7 & 11 & 14 \\
200 & 4.5 & 9 & 16 & 20 \\
200 & 5.5 & 11 & 20 & 24 \\
200 & 6.5 & 12 & 22 & 27 \\
200 & 7.5 & 12 & 23 & 28 \\
200 & 8.5 & 12 & 23 & \\
\hline
\end{tabular}




\section{Freundlich isotherm}

Freundlich isotherm is used for modeling the adsorption on heterogeneous surfaces. This isotherm expressed in equation 1. Freundlich isotherm is used for modelling the adsorption on heterogeneous surfaces. This isotherm can be explained as:

$$
\log \mathrm{x} / \mathrm{m}=1 / \mathrm{n} \log \mathrm{C}+\log \mathrm{K}_{\mathrm{f}}
$$

Where $\mathrm{x}=$ the amount of heavy metal cation absorbed

$$
\mathrm{m}=\text { weight of adsorbate }
$$

Thus $\quad \mathrm{x} / \mathrm{m}=$ amount absorbed per unit weight

$1 / \mathrm{n}=$ adsorption intensity

$\mathrm{C}=$ equilibrium concentration of metal cation

$\mathrm{K}_{\mathrm{f}}=$ Freundlich constant

This linear relationship indicates that the sorption process can be described by Freundlich type isotherm, moreover, the sorption of ions on bentonite clay takes place mainly through the formation of a single monolayer ${ }^{40}$ which shows in Figures 6 and $7 \&$ Table $5 \& 6$. These figures show that Freundlich isotherm curves are linear for both iron and manganese adsorption. A plot of $\log (\mathrm{x} / \mathrm{m})$ versus $\log \mathrm{C}$ yields a straight line with a slop of $1 / \mathrm{n}$ and an intercept of $\log \mathrm{K}_{\mathrm{f}}$ if the data conform to the Freundlich isotherm. Adsorption should decrease with increasing temperature, consequently, $1 / \mathrm{n}$ increase with temperature.

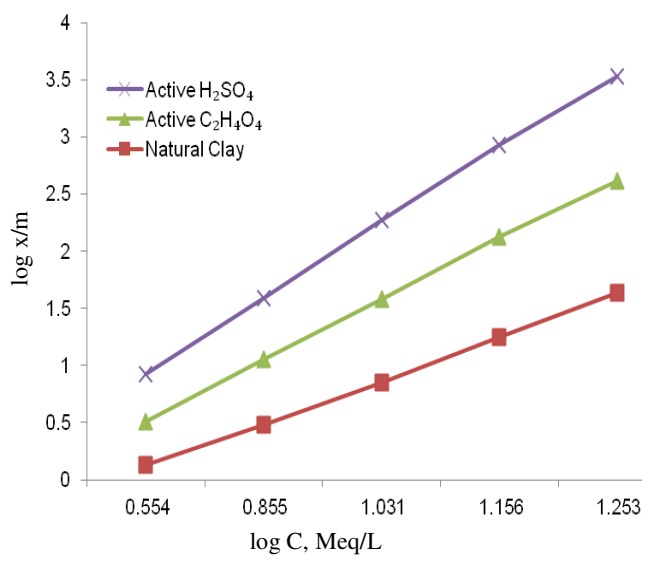

Figure 6. Freundlich adsorption isotherms for interactions of iron on bentonite clay

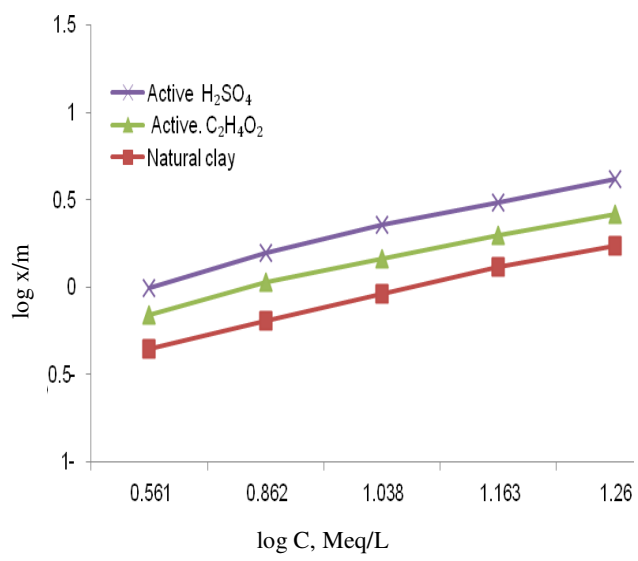

Figure 7. Freundlich adsorption isotherms for interactions of manganese on bentonite clay

Table 5. Amount of $\mathrm{Fe}^{2+}$ ions adsorbed onto bentonite at different concentrations

\begin{tabular}{ccccccccccccc}
\hline $\begin{array}{c}\text { Equilibrium conc. } \\
\text { of } \mathrm{Fe}^{2+}(\mathrm{C})\end{array}$ & \multicolumn{4}{c}{$\begin{array}{c}\text { Amounts of } \mathrm{Fe}^{2+} \\
\text { adsorbed onto } \\
\text { natural clay (x/m) }\end{array}$} & \multicolumn{3}{c}{$\begin{array}{c}\text { Amounts of } \mathrm{Fe}^{2+} \\
\text { adsorbed onto } \\
\text { activated clay with } \\
1 \mathrm{M} \mathrm{C}_{2} \mathrm{H}_{4} \mathrm{O}_{2}(\mathrm{x} / \mathrm{m})\end{array}$} & \multicolumn{4}{c}{$\begin{array}{c}\text { Amounts of } \mathrm{Fe}^{2+} \\
\text { adsorbed onto } \\
\text { activated clay with } \\
1 \mathrm{M} \mathrm{H}_{2} \mathrm{SO}_{4}(\mathrm{x} / \mathrm{m})\end{array}$} \\
\hline $\mathrm{ppm}$ & $\mathrm{meq} / \mathrm{L}$ & $\log \mathrm{C}$ & $\mathrm{ppm}$ & $\mathrm{meq} / \mathrm{g}$ & $\log \mathrm{x} / \mathrm{m}$ & $\mathrm{ppm}$ & $\mathrm{meq} / \mathrm{g}$ & $\log \mathrm{x} / \mathrm{m}$ & $\mathrm{ppm}$ & $\mathrm{meq} / \mathrm{g}$ & $\log \mathrm{x} / \mathrm{m}$ \\
\hline 200 & 3.581 & 0.554 & 76 & 1.361 & 0.134 & 84 & 1.504 & 0.377 & 92 & 1.647 & 0.417 \\
400 & 7.162 & 0.855 & 152 & 2.722 & 0.48 & 168 & 3.008 & 0.578 & 184 & 3.295 & 0.532 \\
600 & 10.743 & 1.031 & 228 & 4.083 & 0.85 & 252 & 4.512 & 0.734 & 276 & 4.942 & 0.694 \\
800 & 14.324 & 1.156 & 287 & 5.139 & 1.25 & 336 & 6.016 & 0.88 & 368 & 6.589 & 0.8 \\
1000 & 17.906 & 1.253 & 359 & 6.428 & 1.64 & 420 & 7.521 & 0.976 & 460 & 8.237 & 0.916 \\
\hline
\end{tabular}


Table 6. Amount of $\mathrm{Mn}^{2+}$ ions adsorbed onto bentonite at different concentrations

\begin{tabular}{cccccccccccc}
\hline $\begin{array}{c}\text { Equilibrium Conc. } \\
\text { of } \mathrm{Mn}^{2+} \text { (C) }\end{array}$ & \multicolumn{4}{c}{$\begin{array}{c}\text { Amounts of } \mathrm{Mn}^{+2} \\
\text { adsorbed onto } \\
\text { natural clay (x/m) }\end{array}$} & \multicolumn{3}{c}{$\begin{array}{c}\text { Amounts of } \mathrm{Mn}^{+2} \\
\text { adsorbed onto } \\
\text { activated clay with } \\
1 \mathrm{M} \mathrm{C}_{2} \mathrm{H}_{4} \mathrm{O}_{2}(\mathrm{x} / \mathrm{m})\end{array}$} & \multicolumn{4}{c}{$\begin{array}{c}\text { Amounts of } \mathrm{Mn}^{+2} \\
\text { adsorbed onto } \\
\text { activated clay } \\
1 \mathrm{M} \mathrm{H}_{2} \mathrm{SO}_{4}(\mathrm{x} / \mathrm{m})\end{array}$} \\
\hline $\mathrm{ppm}$ & $\mathrm{meq} / \mathrm{L}$ & $\log \mathrm{C}$ & $\mathrm{ppm}$ & $\mathrm{meq} / \mathrm{g}$ & $\log \mathrm{x} / \mathrm{m}$ & $\mathrm{ppm}$ & $\mathrm{meq} / \mathrm{g}$ & $\log \mathrm{x} / \mathrm{m}$ & $\mathrm{ppm}$ & $\mathrm{meq} / \mathrm{g}$ & $\log \mathrm{x} / \mathrm{m}$ \\
\hline 200 & 3.641 & 0.561 & 18 & 0.328 & -0.385 & 30 & 0.546 & -0.180 & 42 & 0.764 & -0.04 \\
400 & 7.281 & 0.862 & 37 & 0.673 & -0.172 & 59 & 1.074 & 0.031 & 86 & 1.565 & 0.195 \\
600 & 10.921 & 1.038 & 47 & 0.856 & -0.038 & 78 & 1.420 & 0.162 & 126 & 2.293 & 0.36 \\
800 & 14.562 & 1.163 & 72 & 1.311 & 0.118 & 108 & 1.966 & 0.294 & 168 & 3.058 & 0.485 \\
1000 & 18.202 & 1.26 & 90 & 1.638 & 0.200 & 135 & 2.357 & 0.390 & 210 & 3.822 & 0.582 \\
\hline
\end{tabular}

\section{Conclusion}

Tests were performed to evaluate the use of natural bentonite clay powder and it's sulphuric and acetic acids modified activated forms as adsorbents for iron and manganese removal from aqueous solution. The acidic activation clay showed higher specific surface area than that of the natural clay which making them suitable for use in water purification. Obtained results applied for both elements proved their good efficiency in the adsorption processes. The empirical values are evaluated according to the Freundlich isotherms that are generally used to describe the adsorption processes. It is stated that the isotherm model fit very well. They proved that the sorption process of the investigated elements with the bentonite clay and its acid activated forms take place mainly through the formation of a single monolayer of sorbed species. The bentonite adsorbent proved to be efficient for the elimination of heavy metals from aqueous solutions.

\section{Acknowledgement}

The author is grateful to Prof. Mohamed Nazar Ibrahim for his interest and article reviewed, thanks are also offered to Mr. Mohamed. M. Elmaghrabi for graphs helping and deep grateful to Ms. M. D. Elshiki for her interest and encouragement.

\section{References}

1. Eren E, J Hazard Mater., 2009, 165(1-3), 63-70; DOI:10.1016/j.jhazmat.2008.09.066

2. Pitter P, Hydrochemie, Vydavatelsvi VSCHT, Praha, 2009.

3. Ernst W H O, (Eds.), Decontamination or Consolidation of Metal Contaminated Soils by Biological Means. (In Salomons W, Forstner U and Mader P, Heavy Metals: problems and solutions (141-149), Springer, Berlin), 1995.

4. Li L Y and Li F, J Environ Engg., 2001, 127(5), 420-429; DOI:10.1061/(ASCE)07339372(2001)127:5(420)

5. Al-Juboury A I, Inter J Environ Res., 2009, 3(2), 189-198.

6. Ahmad M K, Islam S, Rahman S, Haque M R and Islam M M, Inter J Environ Res., 2010, 4(2), 321-332.

7. Lipczynska-Kochany E and Kochany J, Chemosphere, 2009, 77(2), 279-284; DOI:10.1016/j.chemosphere.2009.07.036

8 Sprynskyy M, Buszewski B, Terzyk A P, Namiesnik J, J Colloid Interface Sci., 2008, 304(1), 21-8; DOI:10.1016/j.jcis.2006.07.068

9 Liu Z R, Zhou Lm, Wei P, Zeng K, Wen C X and Lan H H, J China University Mining Technol., 2008, 18, 255-260. 
10 Sdiri A, Higashi T, Hatta T, Jamoussi F, Tase N, Chem Engg J., 2011, 172(1), 37-46; DOI:10.1016/j.cej.2011.05.015

11. Zhao X, Jia Q and Zhou W, Korean J Chem Eng., 2009, 26(6), 1729-1732; DOI:10.1007/s11814-009-0241-4

12. Yuce G, Alptekin C, 2013, 70(6), 2827-2837; DOI:10.1007/s12665-013-2343-x

13. Elinder C G, Iron. In: Friberg L, Nordberg G F, Vouk V B, Eds., Handbook on the toxicology of metals, Vol. II. Amsterdam, Elsevier. 1986, 276-297.

14. Knepper WA, Iron. In: Kirk-Othmer encyclopedia of chemical technology, New York, NY, Wiley Inter science, 1981, 13, 735-753.

15. Water Treatment Plant Operation - Volume II. Third Edition, California State University, office of Water Programs, Street, Sacramento, California, 2004, 95819-6025.

16. Ning R Y and Stíth D, The iron, silica and organic polymer triangle. Ultrapure Water, 1997, 14(3), 30-32.

17. Ning R Y and Shen P T L, Ultra pure Water, 1998, 15(4), 37-40.

18. Ning R Y, Desalination Water Treatment, 2009, 12(1-3), 162-168;

DOI:10.5004/dwt.2009.918

19. Veli S and Aly"uz B, J Hazard Mater., 2007, 149(1), 226-233;

DOI:10.1016/j.jhazmat.2007.04.109

20. Anirudhan T S, Bringle C D and Radhakrishnan P G, Chem Engg J., 2012, (200-202), 149-157; DOI:10.1016/j.cej.2012.06.024

21. Pereira V S, Lapolli N M E, Rubens F, Recio L and Ángeles M, Environ Technol., 2013, 34(2), 275-282; DOI:10.1080/09593330.2012.692716

22. Buamah R, Petrusevski B and Schippers J C, J Water Supply: Res Technol-AQUA., 2008, 57(1), 1-11.

23. Nassar M M, Ewida K T, Ebrahiem E E, Magdy Y H and Mheaedi M H, J Environ Sci Health, 2004, 39(2), 421-434; DOI:10.1081/ESE-120027533

24. Ye C, Yang H, Lin J, Zeng H and Yu F, Desalination Water Treatment, 2011, 30(13), 114-121; DOI:10.5004/dwt.2011.1927

25. Jiang J and Ashekuzzaman S M, Current Opinion Chem Engg., 2012, 1(2), 191-199; DOI:10.1016/j.coche.2012.03.008

26. Srinivasan R, Adv Mater Sci Engg. Article ID 872531, 2011, 17pages.

27. Taffarel S R and Rubio J, Minerals Engg., 2009, 22(4), 336-343;

DOI:10.1016/j.mineng.2008.09.007

28. Bhattacharyya K G and Gupta S S, Adv Colloid Interface Sci., 2008, 140(2), 114-131; DOI:10.1016/j.cis.2007.12.008

29. Asmatulur R, Turkish J Eng Env Sci., 2002, 26, 447-453.

30. Woumfo E D, Rivallan M, Minkoulou A H, Nkot E O, Figueras F and Njopwouo D, Open Catal J,. 2012, 5, 31-38.

31. Ning R Y and Shen P T L, Ultrapure Water, 1998, 15(4), 37-40.

32. Eze K A, Nwadiogbu J O and Nwankwere E T, Arch Appl Sci Res., 2012, 4(2), 792-794.

33. Ajemba R O and Onukwuli O D, J Basic Appl Sci Res., 2012, 2(9), 9438-9445.

34. Vogel A I, Quantitative inorganic analysis, Longman, UK, 1974, 136.

35. Forbes E A, Posner A M and Quirk J P, Eur J Soil Sci., 1976, 27(2), 154-166; DOI:10.1111/j.1365-2389.1976.tb01986.x

36. Ajemba RO and Onukwull O D, Physiochem Probl Miner Process, 2013, 49(1), 369381; DOI:10.5277/ppmp130133 
37. Elinder C G, Iron. In: Friberg L, Nordberg G F and Vouk V B, Eds., Handbook on the toxicology of metals, Vol. II. Amsterdam, Elsevier. 1986, 276-297.

38. Kamel M M, Ibrahim M A, Ismael A M and El-Motaleeb M A, Ass Univ Bull Environ Res., 2004, 7(1), 101-109.

39. Bhattacharyya K G and Gupta S S, Chem Engg J., 2008, 136(1), 1-13; DOI:10.1016/j.cej.2007.03.005

40. Veli S and Aly"uz B, J Hazard Mater., 2007, 149(1), 226-233;

DOI:10.1016/j.jhazmat.2007.04.109 